Review

\title{
Anystis baccarum: An Important Generalist Predatory Mite to be Considered in Apple Orchard Pest Management Strategies
}

\author{
Andrew G. S. Cuthbertson ${ }^{1, *}$, Bao-Li Qiu ${ }^{2}$ and Archie K. Murchie ${ }^{3}$ \\ 1 The Food and Environment Research Agency, Sand Hutton, York YO41 1LZ, UK \\ 2 Department of Entomology, South China Agricultural University, Guangzhou 510640, China; \\ E-Mail: baileyqiu@scau.edu.cn \\ 3 The Agri-Food and Biosciences Institute, Newforge Lane, Belfast BT9 5PX, UK; \\ E-Mail: archie.murchie@afbini.gov.uk
}

* Author to whom correspondence should be addressed; E-Mail: andrew.cuthbertson@fera.gsi.gov.uk; Tel.: +44-1904-462-201; Fax: +44-1904-462-111.

Received: 12 May 2014; in revised form: 4 July 2014 / Accepted: 11 July 2014 /

Published: 24 July 2014

\begin{abstract}
The increasing concern over the continued use of pesticides is pressurising apple growers to look for alternatives to chemical pest control. The re-discovery, and subsequent conservation, of the beneficial predatory mite, Anystis baccarum (Linnaeus) (Acari: Anystidae), in Bramley apple orchards in Northern Ireland offers a potential alternative control component for incorporation into integrated pest management strategies. Anystis baccarum readily feeds upon economically important invertebrate pest species including European fruit tree red spider mite, Panonychus ulmi (Koch) (Acari: Tetranychidae) and show a level of compatibility with chemical pesticides. Recent mis-identification by apple growers of this beneficial mite species had resulted in unnecessary pesticide applications being applied within Northern Irish apple orchards. However, dissemination of information to the apple growers and promotion of the benefits this mite offers in apple orchards has helped to conserve its populations. Apple growers, across the United Kingdom, must be encouraged to be aware of $A$. baccarum, and indeed all predatory fauna, within their orchards and seek to conserve populations. In doing so, it will ensure that the British apple market remains an environmentally sustainable production system.
\end{abstract}

Keywords: apple orchard; Anystis baccarum; predatory mite; chemical 


\section{Introduction}

Fruit crops, especially apple (Malus $\times$ domestica Borkh. (Rosaceae)), have a relatively high economic value in the fresh market and therefore cosmetic damage and insect infestation must be kept to a minimum. Insect damaged apple fruit is often only accepted for pulp (i.e., fruit juice or apple pie filler). As a result, control of economically important arthropod pest species must be undertaken.

In non-intensive orchards, phytophagous mite populations can be maintained below economic thresholds by natural acarine predation [1,2]. Much work has been done on the impact of predators, such as Typhlodromus pyri Scheuten (Acari: Phytoseiidae) and Zetzellia mali (Ewing) (Acari: Stigmaeidae), on populations of both European fruit tree red spider mite, Panonychus ulmi (Koch) (Acari: Tetranychidae), and apple rust mite, Aculus schlechtendali (Nalepa) (Acari: Eriophyidae) [3-7]. Although these predators are found in Northern Irish Bramley apple orchards, Cuthbertson and Murchie [8] identified the prostigmatid "whirligig" mite, Anystis baccarum (Linnaeus) (Acari: Anystidae) (Figure 1), as the most abundant predatory mite in the orchards surveyed. The same study also confirmed that there were fewer T. pyri in Northern Irish apple orchards compared to their English counterparts.

Figure 1. Adult female of the beneficial whirligig mite, Anystis baccarum (Photo: Andrew G. S. Cuthbertson ${ }^{\circledR}$ ).

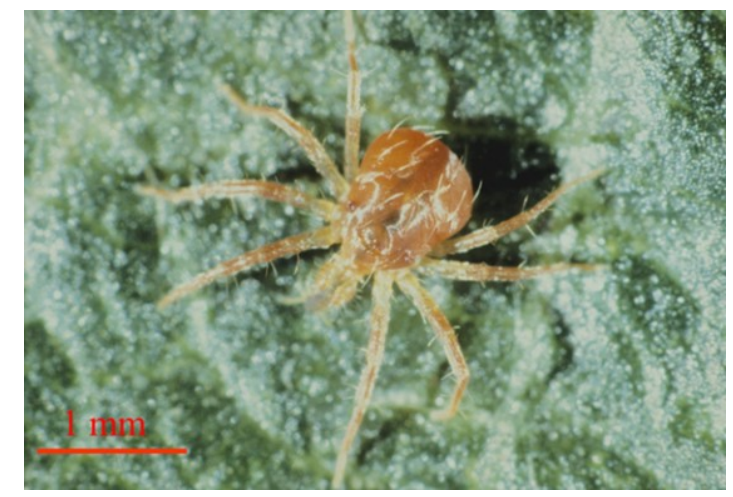

In Northern Ireland, the Bramley's Seedling apple industry is especially important to the rural economy of County Armagh [9]. The annual value of output of the whole apple industry in Northern Ireland is approximately $£ 10$ million [9] with Bramley production in County Armagh comprising an estimated $97 \%$ of this total [10]. Although apple scab (Venturia inaequalis (Cooke) Winter (Ascomycota: Venturiaceae)) (Figure 2) is the largest problem facing apple growers in Northern Ireland [11], invertebrate pest species still pose a significant problem.

Within the United Kingdom (UK), the Agricultural Development and Advisory Service (ADAS), have set out economic thresholds for integrated production of pome fruits [12]. For the apple pests found in Northern Irish orchards the treatment thresholds used on unspecified cultivars in English and Welsh orchards are shown in Table 1. The spray practice in Northern Ireland's orchards is probably derived from ADAS recommendations based on the greater occurrence of a wider range of pests in England and Wales. The economic thresholds assume that populations will increase at a certain rate, but this is likely to differ in the cooler climate of Northern Ireland compared to, for example, Southern England. Mowat and Clawson [13] found winter populations of P. ulmi to exceed ADAS action thresholds in four Northern Irish orchards out of fifteen sampled. Indeed more recently, Cuthbertson and 
Murchie [14] conclusively showed that the UK wide ADAS thresholds were simply too low for Northern Irish orchards, with pest populations often vastly exceeding thresholds with no corresponding damage being recorded.

Figure 2. Scab-infected fruit and foliage (Photo: Andrew G. S. Cuthbertson ${ }^{\complement}$ ).

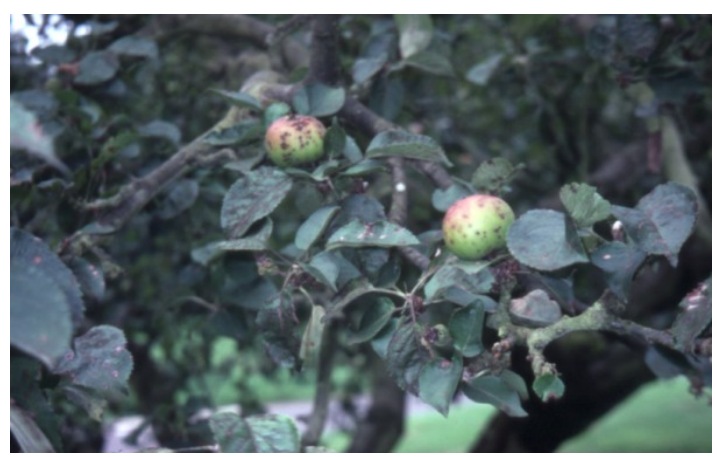

Table 1. Agricultural Development and Advisory Service (ADAS) economic thresholds used for the pest species found in Northern Irish apple orchards [12,14].

\begin{tabular}{|c|c|c|c|}
\hline $\begin{array}{l}\text { Sampling unit per tree (visual } \\
\text { inspection unless beating specified) }\end{array}$ & Pest/disease & Threshold per 25 trees & Action if threshold exceeded \\
\hline
\end{tabular}

\section{Dormant period}

2 vegetative buds in one year shoots

4 branch nodes on 2-3 year old wood

Aculus schlechtendali

Average 10 mites/bud

Treat at mouse ear/green cluster

Panonychus ulmi

$>30$ nodes with $>5$ eggs

Treat with ovicide pre-blossom

Bud-burst to mouse ear

Two outer rosette leaves

Aculus schlechtendali

Average 5 mites/outer

Treat as soon as possible pre-

leaf

blossom

\section{Green cluster to pink bud}

4 trusses Rhopalosiphum insertum

Archips podana

\} Treat at pink bud

\section{Late blossom to petal fall}

2 leaves

Panonychus ulmi

Aculus schlechtendali

Average of 2 mites/leaf

\}Treat as soon as possible

\section{Fortnightly after petal fall}

2 leaves

Pheromone traps
Panonychus ulmi

Archips podana
Average of 5 mites/leaf

Average 2 mites/leaf

$>30$ moths/trap/week
Treat as soon as possible

Treat 7-10 days after threshold catch or immediately if using diflubenzuron

In relation to arthropod pest control in Northern Irish apple orchards, on average two to three sprays of insecticide or acaricide per annum are applied [10]. While this is a small expenditure compared with costs of fungicide application, there are several reasons for the avoidance of unnecessary sprays $[15,16]$ : (1) adverse public attitudes to pesticides have intensified in recent years and this has led to a desire by retailers to reduce dependence on pesticides, especially broad-spectrum neurotoxic compounds that can adversely affect human health or the environment; (2) unnecessary applications of pesticides can 
foster pest resistance to the chemical seriously compromising efficacy; (3) unnecessary chemical applications are a waste of money in an increasingly competitive business; and (4) within a comparatively stable ecosystem like orchards, the ability of natural enemies to control pests, completely or partly, is well documented. Loss of natural enemies means that minor pests can become more damaging as the natural constraints on their populations have been removed [14].

\section{Sampling for Anystis baccarum}

Leaf-dwelling predators, such as the mites T. pyri and Z. mali, can be sampled, among other collecting methods, by leaf washing [17]. However, larger predatory species are generally more mobile and cannot be sampled in this way as they disperse when vegetation is disturbed. Various trapping devises have been described by several authors for trapping insect fauna including earwigs, mites and mirids [18-20]. Using a selection of novel trapping devices, a study within Northern Irish apple orchards determined that A. baccarum was the most abundant beneficial species in the orchards [8]. Straw traps proved best for trapping, not only A. baccarum, but all predatory mites sampled in the study [8].

\section{The Biology of Anystis baccarum}

This species has no males and reproduction is by parthenogenesis [21]. Maturing eggs can easily be seen through the body sclera of the female and, before oviposition, the eggs occupy the entire body of the female [22]. Female mites lay on average two egg clusters comprising 22 eggs per cluster [23]. They will readily lay eggs on moist surfaces (for example, on moist tissue paper in the laboratory) [23]. These are interwoven with transparent filaments (Figure 3a) [24]. Eggs are laid both on the bark of the tree trunks [25] and also in soil litter around the base of the trees [22,23]. Hatching eggs can be recognised by the splitting of the eggshell and the emergence of the legs of the pre-larva (Figure 3b) [24]. The pre-larvae are small (0.2 mm diam.) six legged and immobile. They do not feed and scarcely leave the split eggshells, existing only on egg yolk stored in the intestine [22]. However, after 10-15 days the pre-larvae become active larvae (Figure 3c) and migrate into the crowns of trees where they feed on suitable prey $[22,23]$. The larval stage lasts five to six days and is followed by three nymphal instars which are eight-legged (Figure 1), taking in total about one month to develop into adult form. Adults then live for 15-17 days [22] and can be as large as $1.5 \mathrm{~mm}$ in diameter.

Figure 3. (A) Egg batch of Anystis baccarum; (B) Eggshells splitting and juveniles emerging; (C) Six-legged larval stage (Photos: Andrew G. S. Cuthbertson ${ }^{\mathbb{C}}$ ).

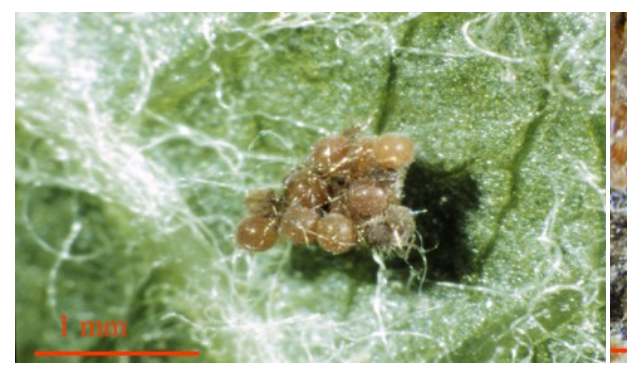

(A)

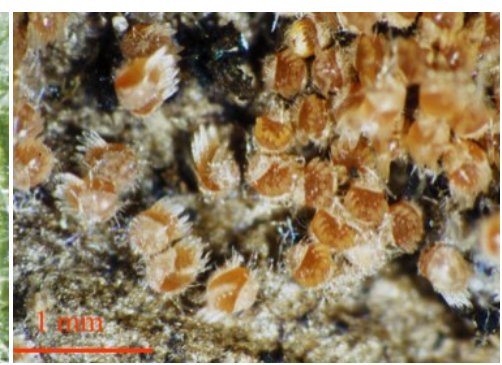

(B)

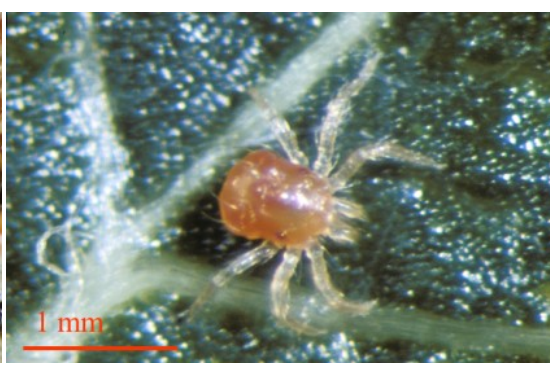

(C) 
All life stages of $A$. baccarum are cannibalistic [26] which makes it difficult to rear them in the laboratory, although Golovach [27] concluded it to be possible but not easy. Newly-hatched larvae may feed on eggs or pre-larvae in the same tube [28]. All other life stages are preyed on by active adult mites. However, in the field it is difficult to assess the importance of this behavior as cannibalism may not occur to the same extent. Cannibalistic behavior has been stated to be an important factor in the dispersal of $A$. baccarum or could be of survival value where the eggs or pre-larvae form part of the diet of larvae hatching in the winter [26].

Anystis baccarum occurs within Northern Irish orchards all year round (Figure 4), with abundance peaking during spring and early summer [23]. At least three generations were observed in the orchards [23], similar to field observations in Guangzhou, China [29].

Figure 4. The phenology of Anystis baccarum in a Northern Irish apple orchard [23].

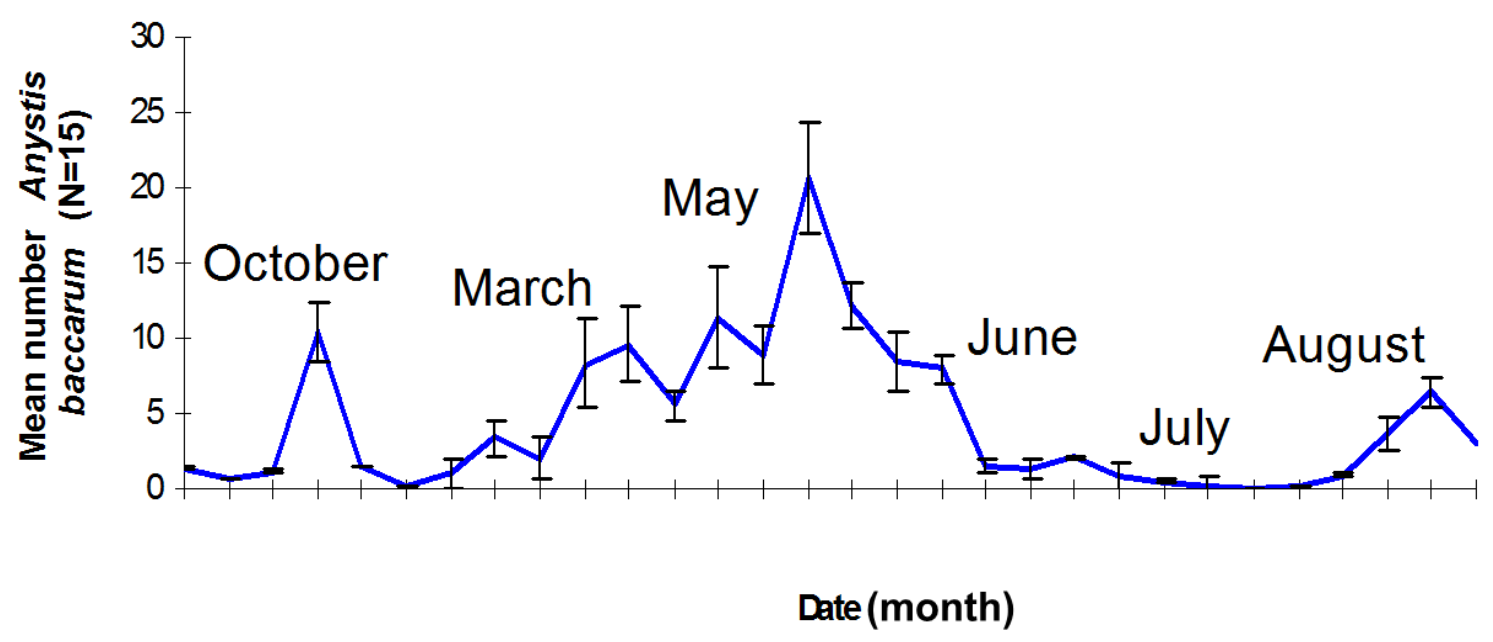

\section{Identification of Anystis baccarum}

Certain characteristics are listed by Meyer and Ueckermann [21] from which A. baccarum may be identified:

(1) Dorsum - the prodorsal shield is almost rounded anteriorly and indented posteriorly, bearing two pairs of long setae and a pair of sensilla. The anterior margin of the idiosoma has also a pair of sensilla. Additionally, two pairs of eyes are located postero-lateral to the prodorsal shield (Figure 5);

(2) Legs - the legs of A. baccarum are densely covered with short smooth setae (Figure 6). Each tarsus terminates in two claws and an empodium with brush like setae present (Figure 7);

(3) Gnathosoma - the palptibia has three claws and the palptarsus bears four small solenidia. There are many long serrated setae of which the terminal setae is the longest. The two chelicerae each contain two setae (Figure 8). The distal half of the reticulated peritremes are flared (Figure 9). 
Figure 5. Scanning electron micrograph showing dorsal view of Anystis baccarum. Anterior margin bears a pair of sensilla (sa); prodorsal shield bears two pairs of long setae $(1 s a+1 s b)$ and a pair of sensilla (sp); two pairs of eyes are located postero-lateral to prodorsal shield (e) (Photo: Andrew G. S. Cuthbertson ${ }^{\circ}$ ).

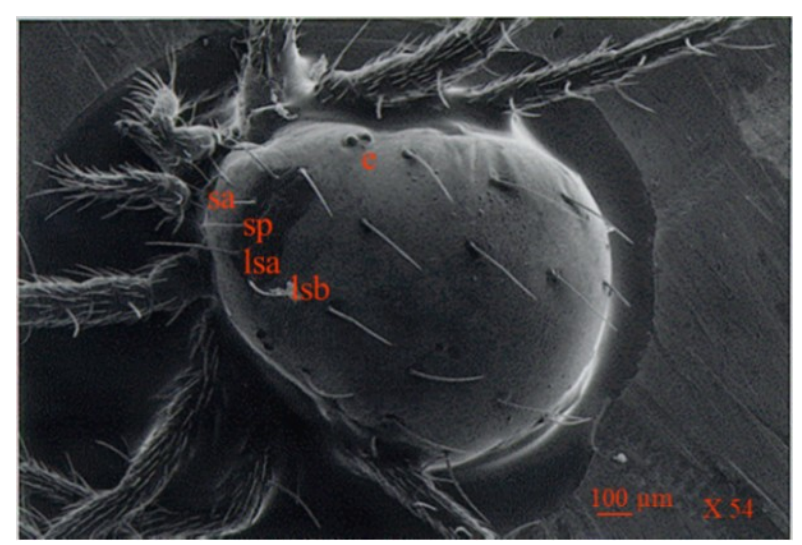

Figure 6. Scanning electron micrograph showing anterior view of Anystis baccarum. Legs densely covered in short smooth setae (ss); anterior margin of idiosoma bearing sensilla (sa); prodorsal shield bearing pair of sensilla (sp); eyes located postero-lateral to prodorsal shield (e) (Photo: Andrew G. S. Cuthbertson ${ }^{\circ}$ ).

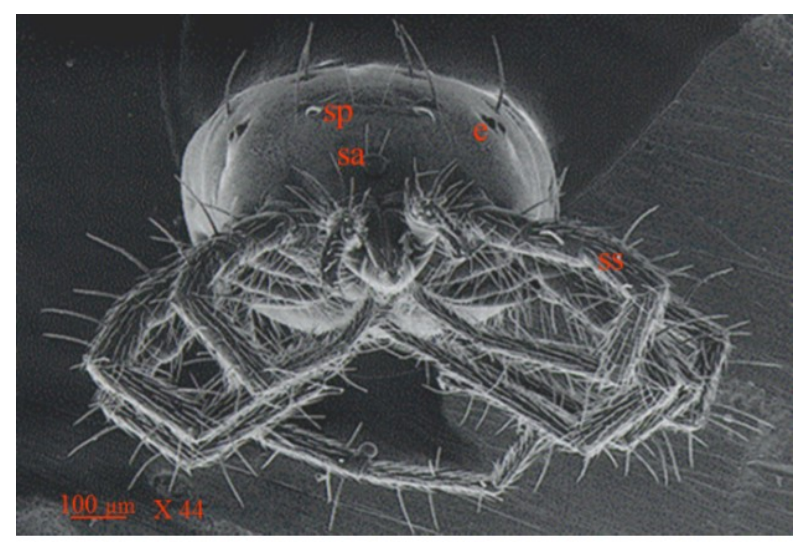

Figure 7. Scanning electron micrograph of Anystis baccarum claw. Each tarsus terminates in two claws (c) and an empodium (e); two brush like setae present at base of claws (bs) (Photo: Andrew G. S. Cuthbertson ${ }^{\complement}$ ).

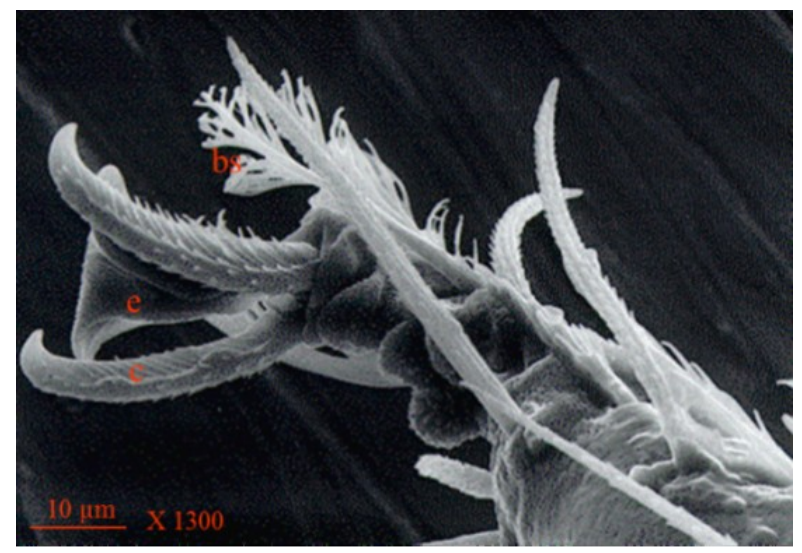


Figure 8. Scanning electron micrograph of gnathosoma region of Anystis baccarum. Palptibia bears three claws (pc); palptarsus bears four small solenidia (s) and many long serrated setae of which the terminal setae is the longest (ts); the chelicerae each bear two setae (cs) (Photo: Andrew G. S. Cuthbertson ${ }^{\circledR}$ ).

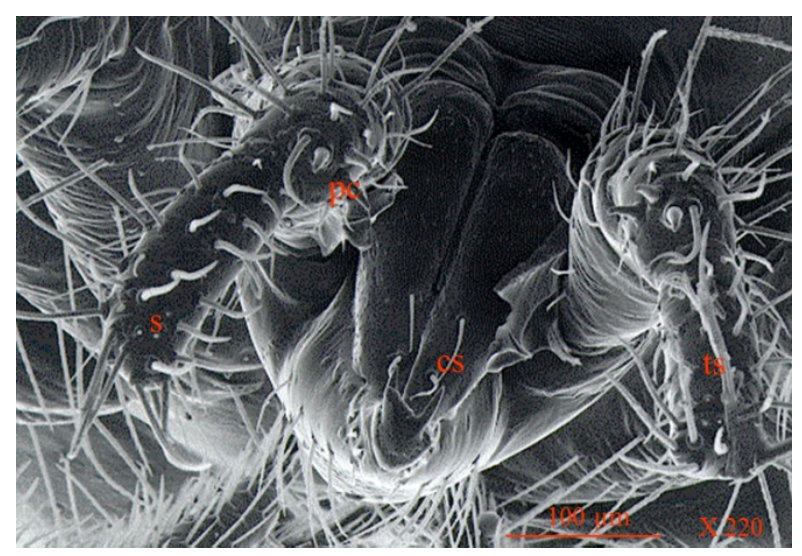

Figure 9. Scanning electron micrograph showing the distal half of the reticulated peritremes (p) flared on Anystis baccarum (Photo: Andrew G. S. Cuthbertson ${ }^{\circledR}$ ).

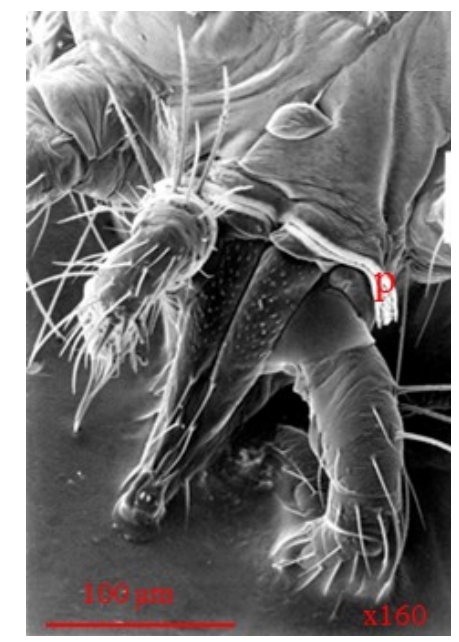

Anystis baccarum adults however, can be easily spotted on the fruit and foliage of apple trees as they are red/orange in color, long-legged, and very mobile. The common name of "Whirligig mite" derives from the mite's rapid, whirling movement — akin to a whirligig spinning toy. The situation among Northern Irish apple growers was that, until recently, they were unaware of the presence of this mite within their orchards. Therefore, they were assuming that any red mite on the apple trees was the pest species, P. ulmi (Figure 10) [30,31]. However, certain characteristics enable A. baccarum adults to be easily identified in the field [15]:

(1) Anystis baccarum ranges in size from 1.0 to $1.5 \mathrm{~mm}$ in diameter. This is a lot larger than $P$. ulmi, which when fully grown is about $0.4 \mathrm{~mm}$ in diameter;

(2) Anystis baccarum moves rapidly over the branches and foliage of the trees, whereas, P. ulmi is relatively sedentary and only found on the under-side of leaves;

(3) Eggs of $P$. ulmi are visible on the twigs of the trees during the winter months, whereas A. baccarum lays eggs under loose bark on the trunk or in the soil surrounding the tree base. 
Figure 10. The European fruit tree red spider mite, Panonychus ulmi (Photo: Andrew G. S. Cuthbertson ${ }^{\mathbb{Q}}$ ).

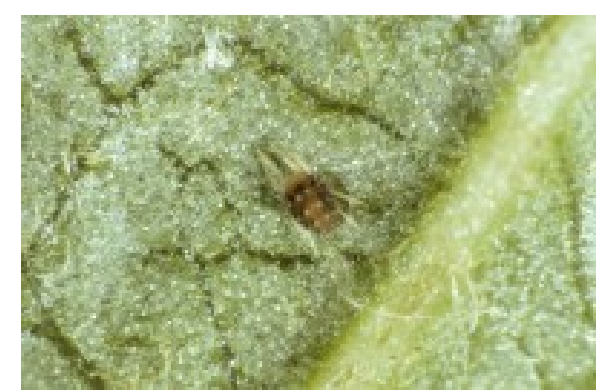

To help overcome the problem of mis-identification of this beneficial mite and to ensure the elimination of unnecessary pesticide sprays, A. baccarum identification cards [32] were designed and distributed around Northern Irish apple growers during the 2009 growing season. These were gratefully received and the information uptake by the local apple growers was very positive. As a result, over the preceding years, several fruit growers have now avoided the need to apply chemical sprays within their orchards against what has now been confirmed as a beneficial species [33].

\section{Potential of Anystis baccarum to Control Invertebrate Pests}

Mites of the genus Anystis have been suggested as bio-control agents of pest arthropods [34] as they have been observed feeding on a variety of prey species throughout the world (Figure 11) (Table 2). In the UK, A. baccarum can become abundant during times of aphid infestation in cereal fields [35], whereas in New Zealand, A. baccarum plays an important role in the predation of tortricid larvae in apple orchards [36]. Anystis baccarum was also found to increase in number during outbreaks of fruit tree red spider mite in Canadian apple orchards [37] and offer control of phytophagous mites in orchards and blackcurrant plantations in Russia [22,38,39]. Much work in China has also proven the predatory potential of $A$. baccarum on pests including the tea leafhopper [40], longan psyllid [41] and the tea red spider mite [42]. As A. baccarum has been known elsewhere to feed on pest species (Table 2) that also occur in British apple orchards [43], this predatory mite will no doubt be an important component of pest management strategies to be employed in the British Isles.

Figure 11. Anystis baccarum attacking (A) Collembola and (B) apple-grass aphid prey (Photos: Andrew G. S. Cuthbertson ${ }^{\odot}$ ).

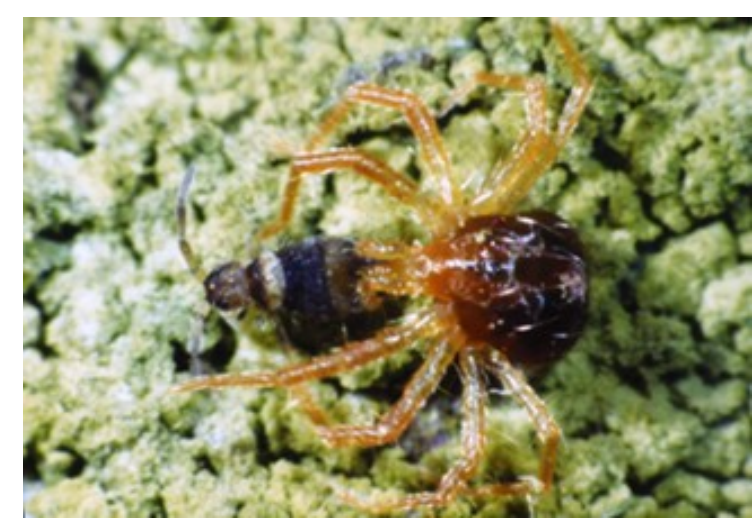

(A)

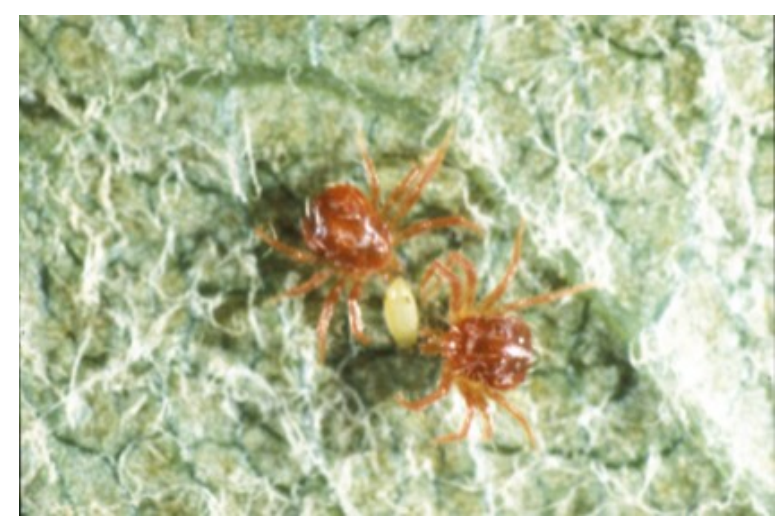

(B) 
Table 2. References to Anystis baccarum feeding on invertebrate pest species.

\begin{tabular}{|c|c|c|c|}
\hline Prey & Crop/Host & Country & Source \\
\hline $\begin{array}{l}\text { Phytophagous mites including Panonychus } \\
\text { ulmi (Fruit tree red spider mite) }{ }^{1,2}\end{array}$ & $\begin{array}{l}\text { Apple orchards, } \\
\text { Black-currant } \\
\text { plantations }\end{array}$ & $\begin{array}{l}\text { Russia, Northern Ireland, } \\
\text { China, England, Canada }\end{array}$ & $\begin{array}{l}{[6,22,23,29,} \\
34,36-38]\end{array}$ \\
\hline $\begin{array}{l}\text { Sitobion avenae, Rhopalosiphum insertum } \\
\text { (Aphids) }{ }^{1}\end{array}$ & Cereals, Apple trees & $\begin{array}{l}\text { England, Northern } \\
\text { Ireland, China }\end{array}$ & {$[23,26,29,35]$} \\
\hline Empoasca vitis (Tea leaf hopper) & Tea plants & China & {$[40]$} \\
\hline Cornegenapsylla sinica (Longan psyllis) ${ }^{2}$ & Orchards & China & [41] \\
\hline $\begin{array}{l}\text { Cydia pomonella, Archips podana (Tortricid } \\
\text { larvae) })^{1,2}\end{array}$ & Apple trees & $\begin{array}{l}\text { New Zealand, Northern } \\
\text { Ireland }\end{array}$ & {$[36,43]$} \\
\hline Erythroneura spp. (Leafhoppers) & Grape vineyards & U.S.A & {$[44]$} \\
\hline Trioza erytreae (Citrus psylla) & Citrus & South Africa & [45] \\
\hline Monelliopsis pecanis (Yellow pecan aphid) ${ }^{1}$ & Pecans & South Africa & [45] \\
\hline Limothrips cerealium, Thrips flavus (Thrips) & $\begin{array}{l}\text { Cereal fields, } \\
\text { flowering plants }\end{array}$ & England & {$[35,46]$} \\
\hline Oulema melanopa (Cereal leaf beetle) & Cereal crops & Sweden & {$[47]$} \\
\hline Cacopsylla spp. (Psyllid eggs) & Sugar beet & Czechoslovakia & {$[48]$} \\
\hline Matsucoccus matsumurae (Pine blast scale) & Pine trees & China & [49] \\
\hline 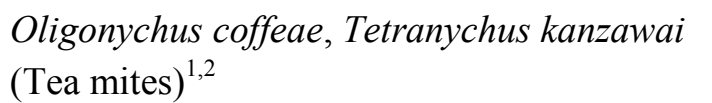 & Tea plants & China, Korea & {$[42,50,51]$} \\
\hline Aculus schlechtendali (Apple rust mite) ${ }^{1,2}$ & Apple trees & Northern Ireland & [52] \\
\hline
\end{tabular}

Pests which are (or are closely related to) Bramley orchard pest species ${ }^{1}$. Anystis baccarum considered to be a bio-control agent ${ }^{2}$.

Studies undertaken in the laboratory to look at the potential of $A$. baccarum as a bio-control agent against orchard invertebrate pest species have indicated that A. baccarum readily feeds upon apple pests in the laboratory, including: P. ulmi, A. schlechtendali, Rhopalosiphum insertum (Walker) (Hemiptera: Aphididae) and Bryobia rubrioculus Scheuten (Acari: Tetranychidae) [23]. The former three species are listed as being of economic importance within Northern Irish orchards [13]. Field studies have also proven the worth of A. baccarum in controlling pest species [41,42]. As A. baccarum feeds on tortricid moth larvae in New Zealand [36], it will therefore presumably also feed upon Archips podana (Scopoli) (Lepidoptera: Tortricidae) and Cydia pomonella (Linnaeus) (Lepidoptera: Tortricidae) larva within UK orchards [43].

\section{Compatibility of Anystis baccarum with Chemicals}

Until recently the only information on the impact of chemical pesticides or fungicides on $A$. baccarum was from a study in Russia in 1974 [53]. Within the British Isles, Cuthbertson and Murchie [54] determined that $A$. baccarum had the potential of being compatible with various chemical fungicides (e.g., dithianon) commonly used for apple scab control. This same study also highlighted a strong link between leaf quality and apple rust mite numbers. Cuthbertson and Murchie [55] also determined that orchard winter-washes and chemical pesticide applications aimed at controlling invertebrate pests had 
detrimental effects on $A$. baccarum populations. The beneficial mite was removed by the chemicals and as a result of this, and presumably depletion of other natural enemies, pest populations, such as, A. schlechtendali, increased within the orchards [14,55]. However, both A. schlechtendali [56] and also $R$. insertum $[57,58]$ may have a beneficial role within the orchards in that they are a valuable food source for sustaining over-wintering populations of $A$. baccarum (Figure 12).

In Canada, work by Laurin and Bostanian [59,60] proved that residues of the fungicides sulphur, captan and myclobutanil were harmless to A. baccarum as were the insecticides methoxyfenozide, acetamiprid, imidacloprid and spinosad. Cuthbertson and Murchie [61] found pirimicarb and tebufenpyrad to have a low toxicity to A. baccarum while phosalone proved very toxic to the mite. Studies in China determined that azadirachtin and imidacloprid had a weak toxicity against A. baccarum [40] while a mixture of abamectin and fenpropathrin proved to be very toxic to A. baccarum [51]. Anystis baccarum therefore offers much potential to be incorporated into current integrated pest management (IPM) strategies within British orchards for arthropod pest control [62].

Figure 12. Anystis baccarum feeding on an overwintering Rhopalosiphum insertum egg (Photo: Andrew G. S. Cuthbertson ${ }^{\circledR}$ ).

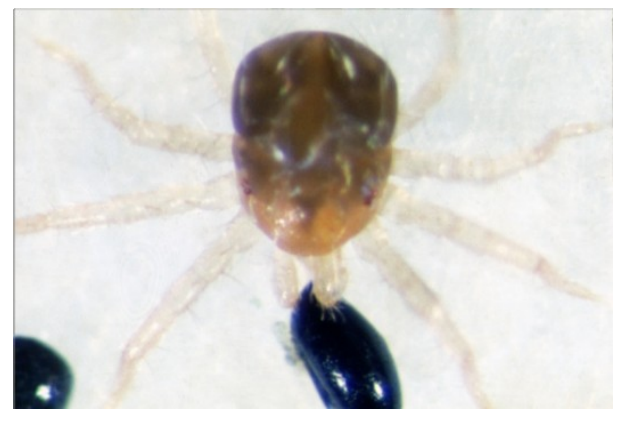

\section{Conclusions}

In the development of orchard IPM programs, generalist predatory mites, such as A. baccarum, must also be fully researched to determine their impact upon pest species and included within any such IPM system implemented. Horticultural advisors and fruit growers alike must be fully aware of the biodiversity that occurs within an orchard ecosystem and ensure the correct identification of pest and beneficial species, thus eliminating unnecessary chemical applications [32]. The inclusion of generalist predatory species within pest control programs has the potential to lead to a more sustainable apple production system, not only within Northern Ireland, but the British Isles as a whole and elsewhere [62,63].

\section{Acknowledgments}

Andrew G. S. Cuthbertson was funded by a Department of Agriculture and Rural Development (Northern Ireland, UK) Studentship.

\section{Author Contributions}

The study was conceived by Andrew G. S. Cuthbertson, Bao-Li Qiu and Archie K. Murchie. All authors contributed to the writing of the manuscript. All authors read and approved the manuscript. 


\section{Conflicts of Interest}

The authors declare no conflict of interest.

\section{References}

1. Hardman, J.M.; Herbert, H.J.; Sanford, K.H.; Hamilton, D. Effects of populations of the European red mite, Panonychus ulmi, on the apple variety Red Delicious in Nova Scotia. Can. Entomol. 1985, 117, 1257-1265.

2. Thistlewood, H.M.A. A survey of predatory mites in Ontario apple orchards with diverse pesticide programs. Can. Entomol. 1991, 123, 1163-1174.

3. Santos, M.A. Evaluation of Zetzellia mali as predator on Panonychus ulmi and Aculus schlechtendali. Environ. Entomol. 1976, 5, 187-191.

4. McMurtry, J.A. The use of phytoseiidae for biological control: Progress and future prospects. In Recent Advances in Knowledge of the Phytoseiidae; Hoy, M.A., Ed.; Agricultural Sciences Publications, University of California: Berkeley, CA, USA, 1982; pp. 23-48.

5. Dicke, M.; Sabelis, M.W.; van den Berg, H. Does prey preference change as a result of prey species being presented together? Analysis of prey selection by the predatory mite Typhlodromus pyri (Acarina: Phytoseiidae). Oecologia 1989, 81, 302-309.

6. Croft, B.A.; MacRae, I.V. Biological control of apple mites by mixed populations of Metaseiulus occidentalis (Nesbitt) and Typhlodromus pyri Scheuten (Acari: Phytoseiidae). Environ. Entomol. 1992, 21, 202-209.

7. Croft, B.A.; Kim, S.S.; Kim, D.I. Leaf residency and interleaf movement of four phytoseiid mites (Acari: Phytoseiidae) on apple. Environ. Entomol. 1995, 24, 1344-1351.

8. Cuthbertson, A.G.S.; Murchie, A.K. Techniques for environmental monitoring of predatory fauna on branches of Bramley apple trees in Northern Ireland. Int. J. Environ. Sci. Technol. 2005, 2, 1-6.

9. Smith, M.; Statistical Review of Northern Ireland Agriculture 2013 (Part of a National Statistics Publication); Department of Agriculture and Rural Development Policy and Economics Division: Belfast, Northern Ireland, UK, 2014; p. 96.

10. Kearns, C.A.; Jess, S.; Matthews, D.; Kelly, T. Northern Ireland Top Fruit Crops 2006. Pesticide Usage Survey Report 217 (Part of a National Statistics Publication); Department of Agriculture and Rural Development for Northern Ireland: Belfast, Northern Ireland, UK, 2006; p. 46.

11. Watters, B.S.; Sturgeon, S.R. An evaluation of fungicides against apple scab (Venturia inaequalis) in Bramley's Seedling. Ann. Appl. Biol. 1990, 116, 38-39.

12. Cross, J.V.; Berrie, A.M. Sampling and assessment of pests and diseases as the basis for decision making in orchards in the UK. Asp. Appl. Biol. 1994, 37, 225-236.

13. Mowat, D.J.; Clawson, S. The need for pest control in Northern Ireland Bramley apple orchards. Crop Prot. North. Br. 1996, 2, 225-230.

14. Cuthbertson, A.G.S.; Murchie, A.K. Environmental monitoring of economically important invertebrate pests in Bramley apple orchards in Northern Ireland. Int. J. Environ. Sci. Technol. 2006, 3, 1-7. 
15. Cuthbertson, A.G.S.; Murchie, A.K. The necessity of correct species identification to avoid unnecessary pesticide application. J. Environ. Res. Dev. 2007, 1, 269-271.

16. Cuthbertson, A.G.S.; Murchie, A.K. Anystis baccarum-An apple orchard assassin. Biologist 2005, 52, 324-327.

17. Zacharda, M.; Pultar, O.; Muska, J. Washing technique for monitoring mites in apple orchards. Exp. Appl. Acarol. 1988, 5, 181-183.

18. Helsen, H.; Vaal, F.; Blommers, L. Phenology of the common earwig Forficula auricularia L. (Dermaptera: Forficulidae) in an apple orchard. Int. J. Pest Manag. 1998, 44, 75-79.

19. McAdam, J.H.; Bell, A.C.; Henry, T. The effect of restoration techniques on flora and microflora of hawthorn-dominated hedges. In Hedgerow Management and Nature Conservation; Watt, T.A., Buckley, G.P., Eds.; Wye College Press: Wye, UK, 1994; pp. 25-32.

20. Stewart, S.D.; Gaylor, M.J. Age, sex, and reproductive status of the tarnished plant bug (Heteroptera: Miridae) colonizing mustard. Environ. Entomol. 1991, 20, 1387-1392.

21. Meyer, M.K.P.S.; Ueckermann, E.A. A taxonomic study of some Anystidae (Acari: Prostigmata). Entomol. Mem. 1987, 68, 1-37.

22. Lange, A.B.; Drozdovskii, E.M.; Bushkovskaya, L.M. Anystid mites-Effective predators of small phytophagous pests (In Russian). Zashchita Rastenii 1974, 1, 26-28.

23. Cuthbertson, A.G.S.; Murchie, A.K. The phenology, oviposition and feeding rate of Anystis baccarum, a predatory mite in Bramley apple orchards in Northern Ireland. Exp. Appl. Acarol. 2004, 34, 367-373.

24. Otto, J.C.; Halliday, R.B. Systematics and biology of a predatory mite (Anystis sp.) introduced into Australia for biological control of redlegged earth mite. Plant Prot. Q. 1991, 6, 181-185.

25. Cuthbertson, A.G.S. The Food and Environment Research Agency, Sand Hutton, York, UK. Personal observation, 2014.

26. Baker, W.V. Some observations on predation in an anystid mite. Entomol. Mon. Mag. 1967, 103, $58-59$.

27. Golovach, G.P. Characteristics of the phenology of the predatory mite Anystis and its rearing under laboratory conditions (In Russian). Vestn. Zool. 1989, 3, 84-86.

28. Sorensen, J.T.; Kinn, D.N.; Doutt, R.L.; Cate, J.R. Biology of the mite, Anystis agilis (Acari: Anystidae): A California vineyard predator. Ann. Entomol. Soc. Am. 1976, 69, 905-910.

29. Wu, H.-J. Preliminary studies on Anystis baccarum (Linnaeus) (Acari: Anystidae). Nat. Enemies Insects 1994, 16, 101-106. (In Chinese).

30. Cuthbertson, A.G.S. Unnecessary pesticide applications in Northern Ireland apple orchards due to misidentification of a beneficial mite species. Res. J. Chem. Environ. 2004, 8, 77-78.

31. Cuthbertson, A.G.S.; Murchie, A.K. European red spider mite-An environmental consequence of persistent chemical pesticide application. Int. J. Environ. Sci. Technol. 2005, 2, 287-290.

32. Cuthbertson, A.G.S.; Murchie, A.K. Ecological benefits of Anystis baccarum in an orchard ecosystem and the need for its conservation. Int. J. Environ. Sci. Technol. 2010, 7, 807-813.

33. Cuthbertson, A.G.S.; Murchie, A.K. Unnecessary pesticide applications: The need for correct identification of a beneficial mite species in Northern Irish apple orchards. In Proceedings of the International Organisation for Biological and Integrated Control of Noxious Animals and 
Plants (IOBC), Working Group on Pesticides and Beneficial Organisms, Namur, Belgium, 25-27 February 2014; p. 4.

34. Gerson, U.; Smiley, R.L. Acarine Biocontrol Agents: An Illustrated Key and Manual; Chapman and Hall: London, UK, 1990; p. 174.

35. El Banhawy, E.M.; Carter, N.; Wynne, I.R. Preliminary observations on the population development of anystid and free-living mesostigmatic mites in a cereal field in southern England. Exp. Appl. Acarol. 1993, 17, 541-549.

36. Baker, R.T. Predation of leafroller larvae by spiders and mites. Weta 1983, 6, 22-23.

37. Putman, W.L.; Herne, D.H.C. The role of predators and other biotic agents in regulating the population density of phytophagous mites in Ontario peach orchards. Can. Entomol. 1966, 98, 808-820.

38. Livshits, I.Z.; Mitrofanov, V.I. Beneficial insects and mites in fruit orchards. Zashchita Rastenii (In Russian). 1981, 6, 49-52.

39. Titov, D.A. Beneficial insects in the orchard (In Russian). Zashchita Rastenii 1987, 2, 56-57.

40. Zeng, Z.-Q.; Zhou, Z.; Wei, Z.-J.; Chen, S.-B.; You, M.-S. Toxicity of five insecticides on predatory mite (Anystis baccarum L.) and their effects on predation to tea leafhopper (Empoasca vitis Göthe) (In Chinese). J. Tea Sci. 2007, 27, 147-152.

41. Qiu, L.-M.; Zhan, Z.-X.; Wu, W. Population dynamics of Anystis baccarum Linnaeus and its control effect on Cornegenapsylla sinica Yang et Li (In Chinese). J. Environ. Entomol. 2011, 33, 529-533.

42. Lioa, D.-Q.; Liang, G.-W.; Cen, Y.-J. Effects of the predation of big red mite Anystis baccarum on tea red mite Oligonychus coffeae. J. Fujian Agric. For. Univ. (Nat. Sci. Ed.) 2010, 39, 117-122. (In Chinese).

43. Cuthbertson, A.G.S.; Murchie, A.K. Environmental monitoring of Archips podana (fruit tree tortrix moth) in Bramley apple orchards in Northern Ireland. Int. J. Environ. Sci. Technol. 2005, 2, 101-104.

44. Jubb, G.L., Jr.; Masteller, E.C.; Lehman, R.D. Survey of arthropods in vineyards of Erie County, Pennsylvania: Acari. Int. J. Acarol. 1985, 11, 201-207.

45. Van den Berg, M.A.; Claassens, V.E.; Maritz, M.; Ueckermann, E.A. Anystis baccarum (Acarina: Anystidae), a newly recorded predator of the citrus psylla, Trioza erytreae (Hem.: Triozidae) and the yellow pecan aphid, Monelliopsis pecanis (Hem.: Aphididae). Inligtingsbull. Inst. Trop. Subtrop. Gewasse 1995, 275, 44-47.

46. Morison, G.D. Observations and records for some British Thysanoptera VII. Thripidae, Thrips flavus Schrank and Thrips brevicornis Priesner. Entomologist 1968, 101, 205-212.

47. Borg, A. The cereal leaf beetle (Oulema melanopa L.), some observations and tests on control (In Swedish). Vaxtskyddsnotiser 1982, 46, 74-80.

48. Lauterer, P. New data on the occurrence, bionomics and taxonomy of some Czechoslovakian Psylloidea (Homoptera). Cas. Morav. Mus. Vedy Prir. 1982, 67, 133-162.

49. Ming, W.-J.; Ge, Q.-J.; Zheng, H.-Y. Studies of some major predaceous natural enemies of Matsucoccus matsumurae (Kuwana) (In Chinese). J. Nanjing Technol. Coll. For. Prod. 1983, 3, 19-29. 
50. Lee, S.-C.; Kim, D.; Kim, S.-S. Ecology of Tetranychus kanzawai and its natural enemies at a tea tree plantation (In Korean). Korean J. Appl. Entomol. 1995, 34, 249-255.

51. Xiong, Z.-H.; Li, B.-T.; Xiong, J.-M.; Yang, Z.-Q.; Luo, L. Predatory function of Anystis baccarum L. to Lipaphis erysimi (Kaltenbach) and its sensitivity to five acaricides (In Chinese). Jiangxi Plant Prot. 2011, 34, 67-70.

52. Cuthbertson, A.G.S.; Bell, A.C.; Murchie, A.K. Impact of the predatory mite Anystis baccarum (Prostigmata: Anystidae) on apple rust mite Aculus schlechtendali (Prostigmata: Eriophyidae) populations in Northern Ireland Bramley orchards. Ann. Appl. Biol. 2003, 142, 107-114.

53. Bushkovskaya, L.M. The effect of chemicals on the mite Anystis (In Russian). Zashchita Rastenii 1974, 10, 53.

54. Cuthbertson, A.G.S.; Murchie, A.K. The impact of fungicides to control apple scab (Venturia inaequalis) on the predatory mite Anystis baccarum and its prey Aculus schlechtendali (apple rust mite) in Northern Ireland Bramley orchards. Crop Prot. 2003, 22, 1125-1130.

55. Cuthbertson, A.G.S.; Murchie, A.K. Environmental impact of an orchard winter wash and early season pesticide applications on both a beneficial and a pest mite species in Bramley apple orchards. Int. J. Environ. Sci. Technol. 2006, 3, 333-339.

56. Cuthbertson, A.G.S.; Murchie, A.K. The role of Aculus schlechtendali (apple-rust mite) in orchard pest management strategies in Northern Ireland. J. Entomol. 2006, 3, 267-270.

57. Cuthbertson, A.G.S.; Murchie, A.K. The life history of Rhopalosiphum insertum (apple-grass aphid) in Bramley's Seedling apple orchards. J. Entomol. 2007, 4, 160-162.

58. Cuthbertson, A.G.S.; Fleming, C.C.; Murchie, A.K. Detection of Rhopalosiphum insertum (apple-grass aphid) predation by the predatory mite Anystis baccarum using molecular gut analysis. Agric. For. Entomol. 2003, 5, 219-225.

59. Laurin, M.C.; Bostanian, N.J. Laboratory studies to elucidate the residual toxicity of eight insecticides to Anystis baccarum (Acari: Anystidae). J. Econ. Entomol. 2007, 100, 1210-1214.

60. Laurin, M.C.; Bostanian, N.J. Short-term contact toxicity of seven fungicides on Anystis baccarum. Phytoparasitica 2007, 35, 380-385.

61. Cuthbertson, A.G.S.; Murchie, A.K. A preliminary study into the direct effect of chemical pesticides on the predatory mite Anystis baccarum. Int. J. Phys. Sci. 2007, 18, 177-180.

62. Cuthbertson, A.G.S.; Murchie, A.K. Anystis baccarum-A predatory mite in UK apple orchards. Res. J. Chem. Environ. 2012, 16, 18-21.

63. Cuthbertson, A.G.S.; Murchie, A.K. Integrated pest management in Bramley's Seedling apple orchards in Northern Ireland. Biol. Stud. 2006, 28, 103-107.

(C) 2014 by the authors; licensee MDPI, Basel, Switzerland. This article is an open access article distributed under the terms and conditions of the Creative Commons Attribution license (http://creativecommons.org/licenses/by/3.0/). 